Berkeley; D. W. Wilson, professor of physiological chemistry, School of Medicine, University of Pennsylvania; P. W. Wilson, professor of bacteriology, University of Wisconsin ; and S. Winstein, professor of chemistry, University of California, Los Angeles.

The following have been elected foreign associates of the Academy : Prof. Max Borm, formerly professor of physics in the Universities of Göttingen and Edinburgh; Dr. Bertil Lindblad, director of the Stockholm Observatory ; Dr. André Lwoff, head of the Department of Microbial Physiology, Institut Pasteur, Paris; and Sir Alexander Todd, professor of chemistry in the University of Cambridge.

\section{TWELFTH GENERAL ASSEMBLY OF THE INTERNATIONAL UNION OF BIOLOGICAL SCIENCES}

THE International Union of Biological Sciences held its twelfth General Assembly in the rooms of the Consiglio Nazionale delle Ricerche in Rome during April 11-16. The following nineteen countries were represented by delegations: Belgium, Canada, Czechoslovakia, Denmark, Egypt, France, German Federal Republic, Great Britain, India, Israel, Italy, Japan, The Netherlands, Norway, Sweden, Switzerland, Union of South Africa, United States, Yugoslavia. At the previous General Assembly, held at Nice in August 1953, the Assembly appointed a Policy Board, under the chairmanship of Prof. Paul Weiss, to advise the Bureau on the future scope and structure of the Union. The Policy Board met in Paris during July 1954, and made a series of recommendations which the Bureau laid before the General Assembly at Rome for discussion and subsequent adoption in statutory form.

Here lay the chief task of the twelfth General Assembly, and it was clear that the national delegations had come determined to set the affairs of the Union on a new foundation. Under the inspired chairmanship of Prof. Sven Hörstadius, the Assembly did indeed create a new body within the framework of a completely fresh set of statutes. The Union is now organized in three divisions, namely : Botany (Plant Biology) ; Zoology (Animal Biology); General Biology. Each division is composed of a number of sections, not necessarily corresponding to the sections of the old Union. On the contrary, the statutes now lay down that "No section shall be accepted unless its admission is requested by a recognised International Association in the discipline it professes; or by at least six National Committees which include representation of that discipline". This means that in future each section will be truly representative of the workers in the particular field of biology it claims to cultivate.

In the new administrative structure, the small Bureau of the old Union disappears. There are now only two organs, the General Assembly and the Executive Committee. The Executive Committee consists of the officers of the Union together with two representatives from each division. The following persons were unanimously elected at Rome on the recommendation of a nominations committee appointed by the General Assembly : President, Sven Hörstadius (Sweden); Vice-President, R. E. Cleland (U.S.A.); Secretary-General, G. Montalenti (Italy); Treasurer, J. Lanjouw (The Netherlands);
Secretary, R. Ulrich (France). Division of Botany : P. Chouard (France), J. Rousseau (Canada); Division of Zoology : E. Handschin (Switzerland), B. Rensch (German Federal Republic); Division of General Biology : A. A. Miles (Great Britain), P. Gaillard (The Netherlands).

The new Executive Committee plans to meet in London in November 1955. London will also be the venue of the next General Assembly in 1958, to be held immediately prior to the Zoological Congress already planned for July of that year.

The General Assembly adopted two important resolutions. The first of these supports the resolution passed by the International Council of Scientific Unions a year ago underlining the potential danger to deep-sea research of the draft articles on the continental shelf framed by the International Law Commission of the United Nations. The second concerns the radiation hazards of large-scale fission and thermonuclear experiments, and the problem of the disposal of atomic waste. The International Union of Biological Sciences urges the. immediate need of a special committee of the International Council of Scientific Unions to report on these matters. This second resolution will be considered by the forthcoming General Assembly of the Council at Oslo in August 1955.

Other business carried out by the Assembly included the following items: The admission of Scientific Psychology as a Section in the Division of General Biology, on the request of the competent bodies in Brazil, Belgium, France, Spain, Switzerland, Japan and the United States. Responsibility for the Type Culture Collections is to be delegated to the Executive Committee of the International Association of Microbiologists, with a recommendation that precedence should be given to specialized collections of micro-organisms in allocating subventions drawn from Unesco. A Commission on Photo-Biology in the Division of General Biology was established. It was decided to send an observer to the forthcoming meeting of the Executive Committee of the ICSU Abstracting Board at Zurich in July 1955. Dr. Anton Bruun (Copenhagen) was appointed to the Special Committee of the International Council for the International Geophysical Year 1957-58. Applications from, the International Unions of Biochemistry and of Physiological Sciences for admission to the International Council of Scientific Unions are to be supported. The Union also decided to support the movement to increase the annual payments to the International Council of Scientific Unions.

An important symposium on "Topics of International Concern in the Life Sciences" was held during the week of the Assembly.

\section{NEW ENGINEERING BUILDING FOR THE UNIVERSITY OF SHEFFIELD}

$T$ HE opening of the new Engineering Building for the University of Sheffield on April 27 by the Minister of Defence, Mr. Selwyn Lloyd, marks the realization of long-planned developments in the engineering departments of the University. By 1945 the University's engineering buildings had become inadequate, even for the equipment then installed, and no more students could be accommodated, 